\title{
KINETICS OF THE ANODIC DISSOLUTION OF IRON IN CONCENTRATED IONIC MEDIA: GALVANOSTATIC AND POTENTIOSTATIC MEASUREMENTS*
}

\author{
J. J. Podestá $\dagger$ and A. J. Arvía \\ Instituto Superior de Investigaciones, \\ Facultad de Química y Farmacia and División Ingenieria Química, \\ Facultad de Ciencias Fisicomatemáticas, Universidad Nacional de La Plata, \\ La Plata, Argentina
}

\begin{abstract}
The anodic dissolution of iron has been studied in concentrated aqueous media by determining potential/current curves using potentiostatic and galvanostatic techniques. The results indicate that the most likely value of Tafel slope in the range of $\mathrm{pH}$ from 0 to 5 is $2 \cdot 3(2 R T / 3 F)$ for the anodic reaction. The agreement between the two techniques is good.

Among the various mechanisms proposed for the reaction, the results are interpreted satisfactorily by means of the reaction scheme recently proposed by Bockris $e t$ al.
\end{abstract}

Résumé-On a étudié la dissolution anodique du fer dans des milieux aqueux concentrés en déterminant les courbes potentiel-courant par deux techniques différentes: potentiostatique et galvanostatique. Les résultats cinétiques montrent que la valeur de la constante de Tafel la plus probable est $2,3(2 R T / 3 F)$ pour la réaction anodique à des valeurs du $\mathrm{pH}$ comprises entre 0 et 5 . La concordance entre les deux techniques est bonne.

Parmi plusieurs mécanismes proposés pour cette réaction, les résultats sont interprétés de manière satisfaisante en appliquant le schéma récemment proposé par Bockris et al.

Zusammenfassung-Es wurde die anodische Aufösung des Eisens in konzentrierten wässrigen Lösungen durch Bestimmung der Strom-Spannungskurven untersucht. Es wurden potentiostatische und galvanostatische Methoden benützt. Die kinetischen Resultate zeigen, dass für $\mathrm{pH}-W e r t e$ von 0 bis 5 der warscheinlichste Wert der Tafelschen Neigung für die anodische Reaktion $2,3(2 R T / 3 F)$ ist. Die Übereinstimmung der verschiedenen Methoden ist gut.

Von den verschiedenen für die Reaktion angegebenen Mechanismen werden die Resultate am besten durch das kürzlich von Bockris und Mitarbeitern vorgeschlagene Reaktionsschema interpretiert.

\section{INTRODUCTION}

THE anodic dissolution of iron has long received much attention for obvious practical reasons, but only in the last few years has reliable information been obtained that can clarify the fundamental phenomena. It is now clear that there is a Tafel relation between potential and current when active iron is anodically dissolved, showing that the reaction is an activated process. To clarify the mechanism of the reaction the Tafel constants must be known; but no agreement between different authors has been achieved, and consequently various mechanisms have been postulated.

Rojter, Juza and Polujan ${ }^{1}$ found $b_{a}$ for the anodic process between 60 and $75 \mathrm{mV}$ depending on the history of the electrode, using electrolytic iron in $\mathrm{M} \mathrm{FeSO}_{4}$; the exchange current density was $3.0 \times 10^{-6} \mathrm{~A} / \mathrm{cm}^{2}$. Stern and Roth ${ }^{2}$ using $4 \% \mathrm{NaCl}$, pH 1.50, obtained $68 \mathrm{mV}$. Okamoto, Nagayama and Sato ${ }^{3}$ found $100 \mathrm{mV}$, using iron in $3 \mathrm{~N} \mathrm{H}_{2} \mathrm{SO}_{4}$. Hoar and Hurlen ${ }^{4}$ found $30 \mathrm{mV}$ and an exchange current density of $3 \times 10^{-11} \mathrm{~A} / \mathrm{cm}^{2}$ using $0.5 \mathrm{M} \mathrm{FeSO}_{4}$ solution containing $0.1 \mathrm{M} \mathrm{NaHSO}_{4}$. Bonhoeffer and Heusler ${ }^{5}$ obtained $30 \mathrm{mV}$ in $\mathrm{NaClO}_{4}$ solutions; this value was also obtained by Kaesche. ${ }^{6}$ Makrides, Komodromos and Hackerman ${ }^{7}$ found $40 \mathrm{mV}$ in

* Manuscript received 26 April 1964.

$\uparrow$ Present address: Department of Metallurgy, University of Cambridge, England. 
$2 \mathrm{M} \mathrm{HCl}$. Gatos, ${ }^{8}$ using $1 \mathrm{~N} \mathrm{H}_{2} \mathrm{SO}_{4}$, found $60 \mathrm{mV}$ when the dissolution was produced in the presence of depolarizing agents. Hoar and Holliday ${ }^{9}$ and Hoar and Farrer ${ }^{10}$ obtained $50-70 \mathrm{mV}$ for the dissolution of mild steel respectively in $\mathrm{H}_{2} \mathrm{SO}_{4}$ solutions at $40^{\circ} \mathrm{C}$ and in dilute solutions containing magnesium, calcium and sodium salts at $25^{\circ} \mathrm{C}$. Makrides ${ }^{11}$ found $39-60 \mathrm{mV}$ by dissolving iron in $\mathrm{H}_{2} \mathrm{SO}_{4}$ solution. Later Hurlen ${ }^{12}$ obtained the value of $29 \mathrm{mV}$ at $25^{\circ} \mathrm{C}$ for iron in aqueous chloride solutions; he confirms this value in recent publications and explains it on the basis of a ratedetermining step for the anodic dissolution of iron involving two iron atoms. Bockris, Drazic and Despic $^{13}$ find $30-70 \mathrm{mV}$ in solutions containing different salts in the presence of a high concentration of ferrous ion.

We have aimed to obtain kinetic data for the anodic dissolution of iron by applying different experimental techniques and avoiding any possibility of having spurious materials in the system. Hydrogen was avoided to eliminate any possibility of its reacting in some way on the metal surface. The present results can thus be compared with those obtained in this laboratory from a study of the kinetics of iron dissolution at the corrosion potential. ${ }^{14}$

\section{Cell design}

\section{EXPERIMENTAL}

The electrolytic cell, Fig. 1, was a double-wall, roundbottom Pyrex vessel having a Lucite cover which held the electrodes, a thermometer and the gas inlet ending with a sintered glass disk. The iron electrode was made from Merck p.a. iron wire. One of its ends was inserted into a Teflon piece placed at the bottom of a glass tube. Electrical contacts could thus be easily made. The electrical circuit was completed with a large surface platinum wire placed around the working electrode. The potential of the working electrode was measured against a saturated calomel electrode (sce) with Haber-Luggin capillary.

The cell was saturated with nitrogen gas, which helped in stirring the solution. The working electrode surface was between 0.1 and $0.2 \mathrm{~cm}^{2}$.

A new electrode was used for each run, except that in few cases iron wires were used twice. In those cases no difference was noticed between different experiments. The iron samples were previously treated with a solution having the same composition as the one later used in the run. The cell was thermostated by circulating water through the double wall jacket, to $\pm 0.05^{\circ} \mathrm{C}$.

\section{Electrical circuitry}

(a) Potential/current-density measurements. A regulated low voltage power pack was used to supply electrical current to the circuit. The current was adjusted by means of resistors and was read with a precision ammeter. The potential of the working electrode was measured $v s$ sce with a Radiometer $\mathrm{PH}-4$ potentiometer.

(b) Potentiostatic measurements. Current-density/potential curves were also obtained with a potentiostat. The potentiostatic circuit, built in the laboratory, was an improved version of the recent design by Hickling. ${ }^{15}$ It is an instrument of relatively slow response $\left(10^{-5} \mathrm{~s}\right)$, but of great stability (better than $\pm 2 \mathrm{mV}$ ). The electrolysis current was supplied by a low tension regulated power pack. The working electrode potential was measured with a potentiometric recorder. The circuit was properly shielded.

(c) Galvanostatic measurements. The galvanostatic circuit was assembled with a 
high tension regulated power pack, a variable resistor of $20 \mathrm{~K} \Omega$, a precision ammeter and a suitable interruptor, all connected in series with the electrolytic cell. Two different devices were used as interruptors. One was a mercury switch, which made a neat cut-off of the current; the other was an electronic repetitive interruptor of variable time, essentially based in the circuit described by Richeson and Eisenberg. ${ }^{16}$

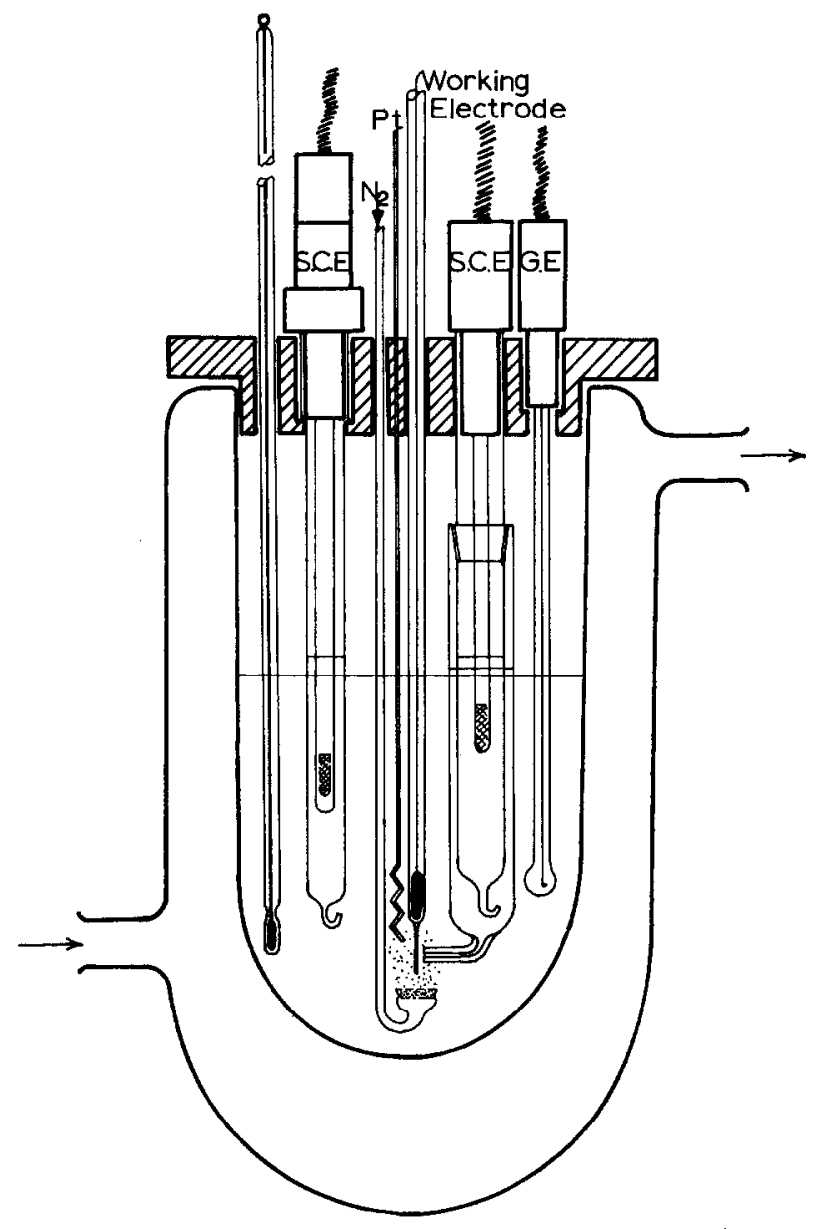

FIG. 1. Cell scheme.

The electrode-potential change was measured when the current was swilched on, and the decay curve when the current was switched off was also determined; both were visualized on the oscilloscope screen and recorded with a conventional camera. A Tektronik 545-A, provided with a type D differential amplifier was employed.

\section{Materials}

The chemicals and solutions described previously ${ }^{14}$ were used. In addition some runs were done with solutions of sodium sulphate, sulphuric acid and ferrous sulphate to reproduce the work of Bockris, Drazic and Despic, ${ }^{13}$ for comparison. 


\section{RESULTS AND INTERPRETATION}

Solutions of sodium perchlorate from 0.2 to $2 \mathrm{M}$, sodium chloride from 0.2 to $2 \mathrm{M}$, sodium nitrate $2 \mathrm{M}$ and sodium sulphate $0.2 \mathrm{M}$ were used at 25 and $50^{\circ} \mathrm{C}$. The hydrogen-ion concentration of this solution was varied between $10^{-1}$ and $10^{-5} \mathrm{M}$ and the ferrous-ion concentration from 0 to $0.5 \mathrm{M}$.

\section{Current-density/potential curves}

In each experiment the corrosion potential was first determined. Starting at this potential the electrode potential was made more positive or negative. For positive potentials the iron dissolution reaction predominates, while at more negative potentials the cathodic processes occur preferentially. Each experiment was indifferently

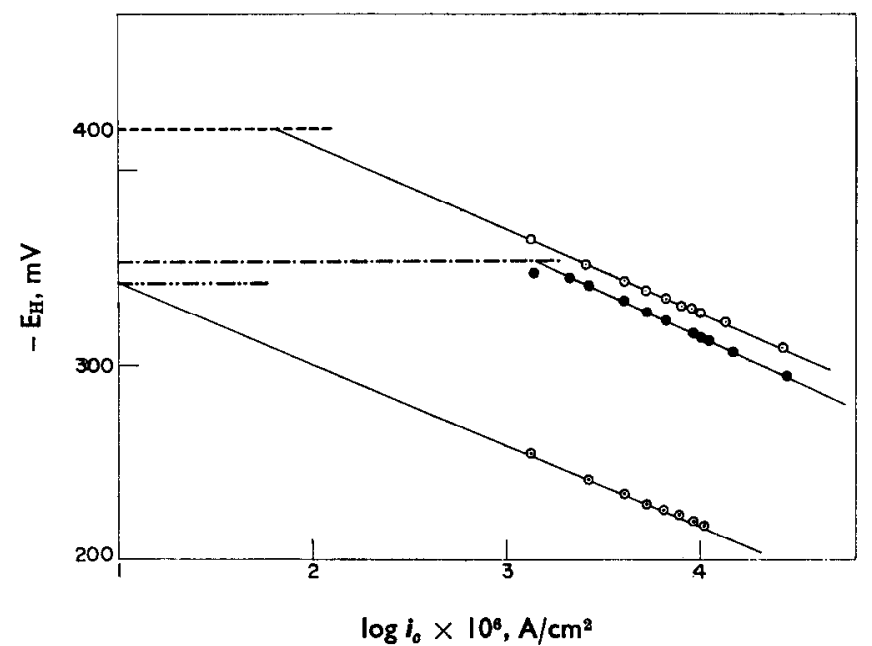

FIg. 2. Anodic Tafel plots.

$E_{e}$, corrosion potential.

Runs $33(0), 31(\bullet)$ and $20(\odot)$.

started by studying either the cathodic or the anodic processes; the order did not affect the results. To avoid any serious interference due to an appreciable change of the iron surface, the experiments were done in the shortest possible time. Some of the polarization curves are shown in Figs. 2 and 3; all potentials are on the normal hydrogen scale. ${ }^{17}$ For the experiments donc at different temperatures, isothermal temperature coefficients were taken from de Bethune, Licht and Swendeman. ${ }^{18}$ The results show the following features. The data for the anodic reaction fit Tafel lines; the slopes are given in Tables 1 to 5 , together with other magnitudes obtained as described later. In Figs. 2 and $3, E_{c}$ is the experimental corrosion potential, and $E_{r}$ the reversible potential of the iron electrode, calculated with Nernst equation, whence the ferrous ion activity could be estimated. Extrapolation of the Tafel line for the anodic reaction to the corrosion potential yields the corrosion current-density of the process, and extrapolation to the reversible potential yields the exchange currentdensity for the iron electrode. The cathode curves present a more complex shape, which corresponds to two simultaneous phenomena occurring on the electrode. The shape depends on the existence of iron ions in the solution. 


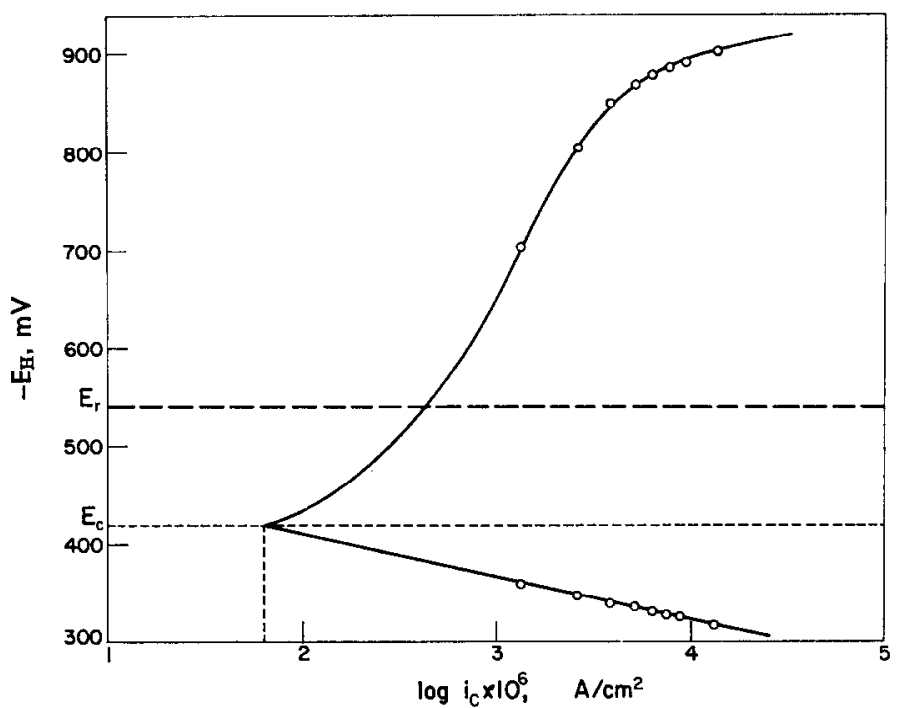

FIG. 3. Tafel plots for anodic and cathodic reactions.

$E_{\theta}$, corrosion potential; $E_{r}$, reversible potential of iron electrode. $2 \mathrm{M} \mathrm{NaCl}, 50^{\circ} \mathrm{C}$, $\mathrm{pH}=4.16, a_{\left(\mathrm{Fe}^{2+}\right)}=0.7 \times 10^{-3}$.

\section{Decay and build-up curves}

Build-up curves for the electrode potential at constant current density show a relatively low response as compared to other electrode processes; the same is true for the decay curves. Build-up curves for the anodic potential have the following characteristics: initially there is a rapid increase of the potential reaching a maximum value $\left(E_{\max }\right)$ and then there is a slow decrease to the steady value. The slope at the origin of the potential/time curves allows immediately the calculation of the doublelayer differential capacitance of the electrode at the corrosion potential. These values, Tables 6,7 and 9 , are relatively high.

TABLE 1

\begin{tabular}{|c|c|c|c|c|c|c|}
\hline \multicolumn{7}{|c|}{$2 \mathrm{M} \mathrm{NaClO}_{4} \quad 50.0^{\circ} \mathrm{C}$} \\
\hline Run & $\mathrm{pH}$ & $a_{\mathrm{Fe}^{2+}}$ & $\begin{array}{l}b_{a} \\
\mathrm{mV}\end{array}$ & $\begin{array}{c}E_{c} \\
\mathrm{mV}\end{array}$ & $\begin{array}{c}i_{\text {corr }} \\
\mathbf{A} / \mathrm{cm}^{2}\end{array}$ & $\stackrel{i_{0}}{\mathrm{~A} / \mathrm{cm}^{2}}$ \\
\hline 44 & 1.02 & $0.80 \times 10^{-2}$ & 40 & -282 & $2.8 \times 10^{-3}$ & $\rightarrow$ \\
\hline 31 & 1.44 & $0.95 \times 10^{-1}$ & 45 & -353 & $1.4 \times 10^{-3}$ & $8.9 \times 10^{-5}$ \\
\hline 30 & 1.49 & $5.40 \times 10^{-3}$ & 27 & -360 & $5.0 \times 10^{-4}$ & - \\
\hline 29 & 1.62 & $0.30 \times 10^{-2}$ & 35 & -321 & $3.2 \times 10^{-4}$ & - \\
\hline 27 & $2 \cdot 26$ & $0.70 \times 10^{-3}$ & 46 & -391 & $8.9 \times 10^{-4}$ & $4.4 \times 10^{-7}$ \\
\hline
\end{tabular}

TABLE 2

$2 \mathrm{M} \mathrm{NaCl} \quad 50 \cdot 0^{\circ} \mathrm{C}$

\begin{tabular}{ccccccc}
\hline Run & $\mathrm{pH}$ & $a_{\mathrm{Fe}^{2+}}$ & $\begin{array}{c}b_{a} \\
\mathrm{mV}\end{array}$ & $\begin{array}{c}E_{c} \\
\mathrm{mV}\end{array}$ & $\begin{array}{c}i_{\text {corr }} \\
\mathbf{A} / \mathrm{cm}^{2}\end{array}$ & $\begin{array}{c}i_{0} \\
\mathbf{A} / \mathrm{cm}^{2}\end{array}$ \\
\hline 20 & 2.13 & $0.80 \times 10^{-3}$ & 44 & -343 & $1.0 \times 10^{-5}$ & $1.0 \times 10^{-9}$ \\
25 & 3.94 & $0.20 \times 10^{-4}$ & 35 & -402 & $2.8 \times 10^{-6}$ & $1.6 \times 10^{-8}$ \\
33 & 4.16 & $0.70 \times 10^{-3}$ & 45 & -421 & $6.3 \times 10^{-5}$ & $4.4 \times 10^{-2}$ \\
\hline
\end{tabular}


TABLe 3

$2 \mathrm{M} \mathrm{NaCl} \quad 25 \cdot 0^{\circ} \mathrm{C}$

\begin{tabular}{ccccccc}
\hline Run & $\mathrm{pH}$ & $a_{\mathrm{Fe}^{2+}}$ & $\begin{array}{c}b_{a} \\
\mathrm{mV}\end{array}$ & $\begin{array}{c}E_{\mathrm{c}} \\
\mathrm{mV}\end{array}$ & $\begin{array}{c}i_{\mathbf{c o r r}} \\
\mathbf{A} / \mathrm{cm}^{2}\end{array}$ & $\begin{array}{c}i_{\mathbf{0}} \\
\mathbf{A} / \mathrm{cm}^{2}\end{array}$ \\
\hline 37 & $\mathbf{1 . 7 8}$ & $2.97 \times 10^{-3}$ & 54 & -210 & $7.5 \times 10^{-5}$ & $4.0 \times 10^{-8}$ \\
43 & 2.42 & $1.67 \times 10^{-3}$ & 48 & -240 & $1.2 \times 10^{-3}$ & - \\
42 & 2.48 & $0.54 \times 10^{-3}$ & 32 & -248 & $29 \times 10^{-4}$ & $-2.5 \times 10^{-8}$ \\
35 & 2.70 & $0.67 \times 10^{-1}$ & 49 & -254 & $5.0 \times 10^{-5}$ & $3.5 \times 10^{-9}$ \\
36 & 2.73 & $0.33 \times 10^{-3}$ & 44 & -258 & $4.5 \times 10^{-5}$ & $5.0 \times 10^{-3}$ \\
\hline
\end{tabular}

TABLE 4

$0.2 \mathrm{M} \mathrm{NaCl} \quad 50.0^{\circ} \mathrm{C}$

\begin{tabular}{ccccccc}
\hline Run & $\mathrm{pH}$ & $a_{\mathrm{Fe}^{2+}}$ & $\begin{array}{c}b_{a} \\
\mathrm{mV}\end{array}$ & $\begin{array}{c}F_{\mathrm{o}} \\
\mathrm{mV}\end{array}$ & $\begin{array}{c}i_{\text {corr }} \\
\mathbf{A} / \mathrm{cm}^{2}\end{array}$ & $\begin{array}{c}i_{0} \\
\mathrm{~A} / \mathrm{cm}^{2}\end{array}$ \\
\hline 14 & 2.12 & $0.60 \times 10^{-3}$ & 42 & -292 & $7.0 \times 10^{-4}$ & $1.0 \times 10^{-9}$ \\
$\mathbf{2 2}$ & 2.91 & $0.15 \times 10^{-4}$ & 37 & 380 & $3.1 \times 10^{-4}$ & $1.0 \times 10^{-10}$ \\
18 & 3.34 & $\mathbf{0 . 1 8} \times 10^{-4}$ & 58 & -410 & $5.6 \times 10^{-4}$ & $3.5 \times 10^{-6}$ \\
19 & 3.69 & $0.31 \times 10^{-4}$ & 61 & -425 & $5.2 \times 10^{-4}$ & - \\
\hline
\end{tabular}

TABLE 5

$2 \mathrm{M} \mathrm{NaNO}_{2} \quad 50.0^{\circ} \mathrm{C}$

\begin{tabular}{ccccccc}
\hline Run & $\mathrm{pH}$ & $a_{\mathrm{Fe}^{2+}}$ & $\begin{array}{c}b_{a} \\
\mathrm{mV}\end{array}$ & $\begin{array}{c}E_{e} \\
\mathrm{mV}\end{array}$ & $\begin{array}{c}i_{\text {corr }} \\
\mathrm{A} / \mathrm{cm}^{2}\end{array}$ & $\begin{array}{c}\boldsymbol{i}_{0} \\
\mathrm{~A} / \mathrm{cm}^{2}\end{array}$ \\
\hline 10 & 2.66 & $0.95 \times 10^{-4}$ & 41 & -338 & $9.0 \times 10^{-4}$ & $\mathbf{1 . 2} \times 10^{-8}$ \\
11 & $\mathbf{2 . 7 6}$ & $0.17 \times 10^{-3}$ & 43 & -346 & $6.3 \times 10^{-4}$ & $8.0 \times 10^{-8}$ \\
\hline
\end{tabular}

TABLE 6

$2 \mathrm{M} \mathrm{NaClO}_{4}, \quad 0 \cdot 1 \mathrm{M} \mathrm{Fe}\left(\mathrm{ClO}_{4}\right)_{2} \quad \mathrm{pH} \mathrm{0.20} \quad 15 \cdot 5^{\circ} \mathrm{C}$

\begin{tabular}{ccccccc}
\hline $\begin{array}{c}i_{a} \\
\mathrm{~mA} / \mathrm{cm}^{2}\end{array}$ & $\begin{array}{c}b_{a} \\
\mathrm{mV}\end{array}$ & $\begin{array}{c}C \\
\mu \mathrm{F} / \mathrm{cm}^{2}\end{array}$ & $\begin{array}{c}E_{\max } \\
\mathrm{mV}\end{array}$ & $\begin{array}{c}\tau_{\max } \times 10^{3} \\
\mathrm{~s}\end{array}$ & $\begin{array}{c}i_{c} \\
\mathrm{~mA} / \mathrm{cm}^{2}\end{array}$ & $\begin{array}{c}\left(b_{c}\right)_{\mathrm{H}} \\
\mathrm{mV}\end{array}$ \\
\hline $1 \cdot 30$ & 18 & 1282 & 25 & $73 \cdot 7$ & $2 \cdot 41$ & 130 \\
$2 \cdot 22$ & 21 & 1071 & 37 & 50.0 & $5 \cdot 43$ & 113 \\
$5 \cdot 43$ & 23 & 955 & 62 & 32.5 & $9 \cdot 78$ & 90 \\
$16 \cdot 3$ & 45 & 920 & 91 & 14.0 & 12.6 & 118 \\
$26 \cdot 6$ & 50 & 1160 & 98 & $11 \cdot 5$ & 16.8 & 118 \\
$48 \cdot 9$ & 42 & 1138 & 120 & 6.8 & & \\
$48 \cdot 9$ & 69 & 1064 & 122 & 6.6 & & \\
$81 \cdot 5$ & 69 & 1500 & 132 & $5 \cdot 5$ & & \\
\hline
\end{tabular}

TABLE 7

$2 \mathrm{M} \mathrm{NaClO}_{4}, \quad 0.1 \mathrm{M} \mathrm{Fe}\left(\mathrm{ClO}_{4}\right)_{2} \quad \mathrm{pH} 2.45 \quad 15.0^{\circ} \mathrm{C}$

\begin{tabular}{cccrc}
\hline $\begin{array}{c}i_{a} \\
\mathrm{~mA} / \mathrm{cm}^{2}\end{array}$ & $\begin{array}{c}b_{a} \\
\mathrm{mV}\end{array}$ & $\begin{array}{c}C \\
\mu \mathrm{F} / \mathrm{cm}^{2}\end{array}$ & $\begin{array}{c}E_{\max } \\
\mathrm{mV}\end{array}$ & $\begin{array}{c}\tau_{\max } \times 10^{3} \\
\mathrm{~s}\end{array}$ \\
\hline 1.30 & - & 220 & 50 & 40.0 \\
3.28 & - & 227 & 67 & 16.5 \\
3.28 & - & 186 & 76 & 15.0 \\
6.52 & 32 & 300 & 77 & 11.0 \\
9.95 & 39 & 220 & 80 & 5.5 \\
16.3 & 33 & 285 & 99 & 5.5 \\
27.2 & 50 & 366 & 103 & 3.9 \\
27.2 & 46 & 485 & 110 & 4.0 \\
61.0 & 51 & 530 & 129 & 3.1 \\
\hline
\end{tabular}




\begin{tabular}{|c|c|c|c|c|}
\hline \multicolumn{5}{|c|}{ TABLE 8} \\
\hline \multicolumn{2}{|c|}{$2 \mathrm{M} \mathrm{NaClO}_{4}$} & pH 5.00 & \multicolumn{2}{|c|}{$15.0^{\circ} \mathrm{C}$} \\
\hline $\begin{array}{c}i_{a} \\
\mathrm{~mA} / \mathrm{cm}^{\mathrm{s}}\end{array}$ & $\begin{array}{c}b_{a} \\
\mathrm{mV}\end{array}$ & $\begin{array}{l}E_{\max } \\
\mathrm{mV}\end{array}$ & $\tau_{\mathrm{mg}}$ & $5 \times 10^{3}$ \\
\hline $1 \cdot 14$ & 34 & - & & - \\
\hline $1 \cdot 14$ & 42 & - & & - \\
\hline 4.35 & 36 & - & & - \\
\hline $4 \cdot 35$ & 36 & - & & - \\
\hline $10 \cdot 9$ & 46 & 300 & & $5 \cdot 0$ \\
\hline $2 \mathrm{M} \mathrm{NaClO}_{4}$, & $0.5 \mathrm{M}$ & $\begin{array}{l}\text { ABLE } 9 \\
\mathrm{e}\left(\mathrm{ClO}_{4}\right)_{2}\end{array}$ & pH 2.20 & $25 \cdot 0^{\circ} \mathrm{C}$ \\
\hline $\begin{array}{c}i_{a} \\
\mathrm{~mA} / \mathrm{cm}^{2}\end{array}$ & $\begin{array}{c}b_{a} \\
\mathrm{mV}\end{array}$ & $\begin{array}{c}C \\
\mu \mathrm{F} / \mathrm{cm}^{2}\end{array}$ & $\begin{array}{c}i_{c} \\
\mathrm{~mA} / \mathrm{cm}^{2}\end{array}$ & $\begin{array}{l}b_{c_{\mathrm{Fe}}} \\
\mathrm{mV}\end{array}$ \\
\hline $7 \cdot 09$ & 34 & 1098 & $2 \cdot 28$ & 82 \\
\hline 8.96 & 33 & 963 & $5 \cdot 43$ & 68 \\
\hline $14 \cdot 8$ & 42 & 1110 & 10.9 & 43 \\
\hline $17 \cdot 3$ & 39 & 1404 & $16 \cdot 3$ & 63 \\
\hline $19 \cdot 5$ & 44 & 1858 & $27 \cdot 2$ & 55 \\
\hline $19 \cdot 5$ & 44 & 1890 & $54 \cdot 3$ & 64 \\
\hline $22 \cdot 5$ & 42 & 1870 & $54 \cdot 3$ & 45 \\
\hline $40 \cdot 8$ & 41 & 2700 & & \\
\hline 40.8 & 40 & 2849 & & \\
\hline 81.5 & 43 & - & & \\
\hline
\end{tabular}

The maximum potential reached in the build-up curve for the anodic reaction depends on the current density. When the maximum overpotential is plotted against $\log$ (current density), it gives a fairly good Tafel line, Fig. 4, of slope $2 \cdot 3 R T / F$. The extrapolation of this line to the corrosion potential yields a corrosion current that coincides with the one given earlier. The time needed for the electrode to reach the maximum potential also depends on the current density.

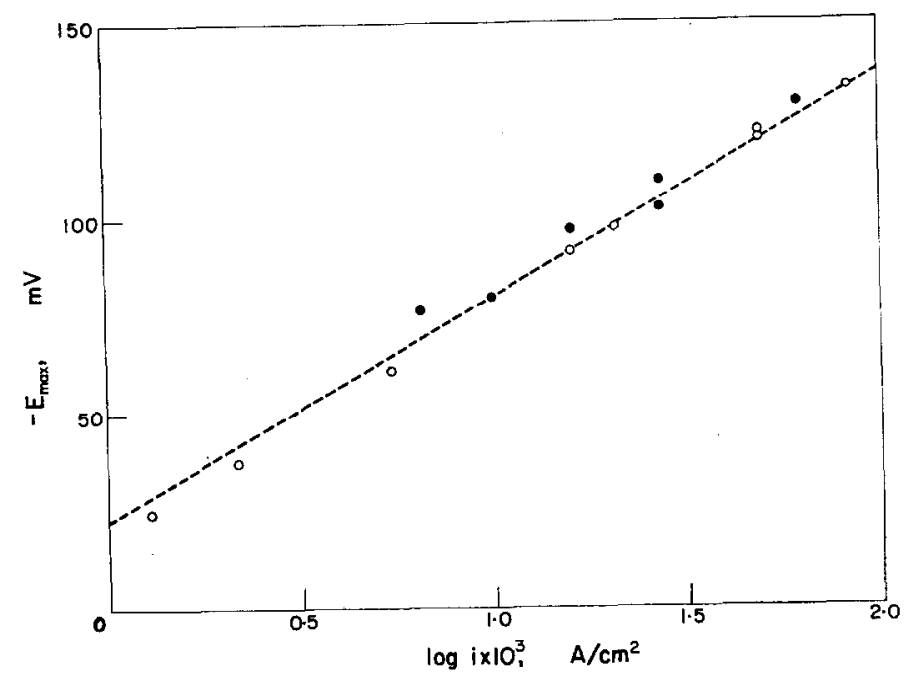

FIG. 4. $E_{\max }$ (from build-up curves) $v s . \log i$.

e, $2 \mathrm{M} \mathrm{NaClO}_{4}, 0.1 \mathrm{M} \mathrm{Fe}\left(\mathrm{ClO}_{4}\right)_{2} \cdot \mathrm{pH} 2.45,15.5^{\circ} \mathrm{C}, i_{\text {corr }}$ (extrap) $2.4 \times 10^{-4} \mathrm{~A} / \mathrm{cm}^{2}$.

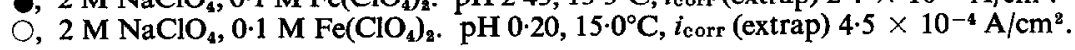


Another effect also shown in build-up curves for the cathodic process has been observed in systems containing ferrous ions. When this ion is present a transition time is observed, corresponding to the theoretical one given by chronopotentiometry. The transition time depends on the square of the concentration of the diffusing species and varies inversely with the square of the current density. ${ }^{19}$ The transition times are of the order of $1 \mathrm{~s}$ and less, Figs. 5 to 8.

The anodic decay curves were obtained as usual at different current densities The data can be linearized by plotting the overpotential, $\eta_{a}$, as a function of $\log t$. This relationship is predicted when activated steps are kinetically significant in the mechanism of electrochemical reactions. The slope of $\eta_{a} v s \log t$ plot is equivalent to a Tafel slope for an instantaneous situation of the electrode surface. Tafel slopes from the decay curves have been obtained at current densities from $1.3 \times 10^{-3}$ to $1.6 \times 10^{-1} \mathrm{~A} / \mathrm{cm}^{2}$.

The decay curves also show potential minima, which appear at much longer times than those at which the maximum of the build-up curves was observed. These minima cannot be determined with accuracy.

Similar experimental information has been obtained for the cathodic reaction. The $\eta_{c} v s \log t$ plots were also linear, with different slopes according to the composition of the solution. When a large excess of ferrous ion was present, the slope was close to $2 \cdot 3 R T / F$ while in the absence of this ion the slope was near $2(2 \cdot 3 R T / F)$.

Most of the experimental results for the anodic dissolution gave Tafel slopes of $\frac{2}{3}(2 \cdot 3 R T / F) \pm 10 \mathrm{mV}$, the bulk of them within $\pm 5 \mathrm{mV}$. Exceptionally, the slopes were as low as $20 \mathrm{mV}$, and in a few as high as $70 \mathrm{mV}$. At $\mathrm{pH}<1$ the slope tended to be greater than $\frac{2}{3}(2 \cdot 3 R T / F)$. In the range of $\mathrm{pH} 1-4$ the slope was close to $\frac{2}{3}(2 \cdot 3 R T / F)$, as indicated in the tables. In the potentiostatic experiments at $25^{\circ} \mathrm{C}$ the average slope for the anodic Tafel line was $42 \mathrm{mV} \pm 10$.

The Tafel slope for anodic reaction can also be obtained from the initial overpotential of the decay curves or the steady potential reached in build-up curves, referred to the corrosion potential and properly corrected for ohmic drop: they are plotted $v s \log i$ in Fig. 9. If these overpotentials are related to an activated process they must follow a Tafel line within the limits of current density considered. The slopes so obtained are in agreement with the ones mentioned above. Thus by different experimental approaches the value of $\frac{2}{3}(2 \cdot 3 R T / F)$ is satisfactorily confirmed. These plots also yielded,by extrapolation to zero overpotential, corrosion current densities which satisfied the expected values.

\section{The effect of anions}

As shown previously in work on the spontaneous dissolution of iron, the corrosion current decreased when going from perchlorate to chloride solutions. The rate of dissolution was still lower in nitrate solution. Quantitative evaluation of the effect is not yet possible, because the estimated corrosion currents are affected by a larger error than the one previously obtained-they are here found from an extrapolation that is sensitive to small changes in Tafel slope. However, the corrosion current $i_{c}$ depends on $\mathrm{pH}$; approximately, in perchlorate solution $\partial \log i_{c} / \partial \mathrm{pH}=-1$. This is precisely what was previously found by measurement of the anodic dissolution of iron at the corrosion potential. The results obtained for chloride solutions are not accurate enough to give more than qualitative information. 
The exchange current density for the iron electrode depends on the anion; it is much larger for perchlorate than for chloride solutions, as previously indicated by other authors. ${ }^{13}$ For perchlorate solutions, the same type of relationship mentioned for the corrosion current is also found between the exchange current density and $\mathrm{pH}$.

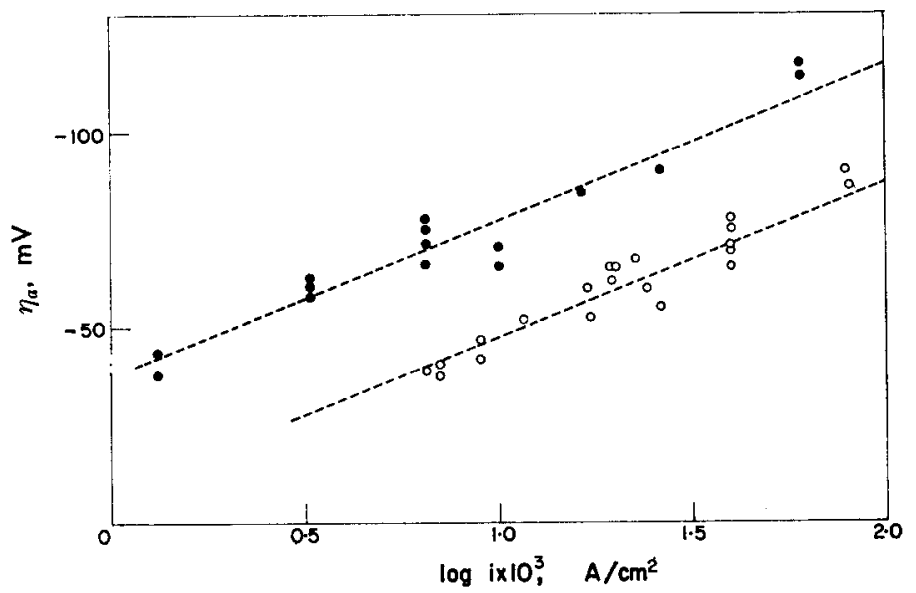

FIG. 9. Activation overpotential (from oscillographic records) vs. $\log i$.

(o) $2 \mathrm{M} \mathrm{NaClO}_{4}, 0.1 \mathrm{M} \mathrm{Fe}\left(\mathrm{ClO}_{4}\right)_{2} . \mathrm{pH}=2.45,15 \cdot 0^{\circ} \mathrm{C}$, $i_{\text {corr }}$ (extrap) $1.2 \times 10^{-4} \mathrm{~A} / \mathrm{cm}^{2}$.

(O) $2 \mathrm{M} \mathrm{NaClO}_{4}, 0.5 \mathrm{M} \mathrm{Fe}\left(\mathrm{ClO}_{4}\right)_{2}, \mathrm{pH} 2.20,25.0^{\circ} \mathrm{C}$, $i_{\text {corr }}$ (extrap) $=6.3 \times 10^{-4} \mathrm{~A} / \mathrm{cm}^{2}$.

\section{DISCUSSION}

A thorough analysis of the kinetics of iron dissolution has been given by Bockris et $a l,,^{13}$ and we now use it to discuss our own results.

We focus attention on the anodic dissolution, because the cathodic deposition reaction involves additional complexity, which it is not yet possible to disentangle. The actual composition of the solution at the surface of an iron cathode is different from that of the bulk solution ${ }^{13}$ and estimation of the surface composition requires an accurate knowledge of the dependence of the exchange current density on $\mathrm{pH}$ : this then allows a correction of the cathodic Tafel line for $\mathrm{pH}$ changes at the electrode surface. Nevertheless our experimental Tafel slope for the cathodic reaction is close to $R T / F$, coinciding with experimental data recorded in the literature.

The Tafel slope for the anodic reaction is in the present case fairly well defined, the values yielded by the different experimental methods being in agreement, as $\frac{2}{3}(R T / F)$ in the range of $\mathrm{pH} 1-4$. This has been explained on the basis of two different mechanisms, that of Kabanov, Burstein and Frumkin ${ }^{20}$ for the dissolution of iron in alkaline media, and that of Bockris, Drazic and Despic ${ }^{13}$ for iron dissolution in acid media.

Our results confirm those of Bockris et al.$^{13}$ According to them, iron dissolution takes place according to

$$
\begin{aligned}
& \text { (I) } \mathrm{Fe}+\mathrm{OH}^{-} \rightleftharpoons \mathrm{FeOH}_{\mathrm{ads}}+\mathrm{e}, \\
& \text { (II) } \mathrm{FeOH}_{\mathrm{ads}} \rightarrow \mathrm{FeOH}_{\mathrm{ads}}++\mathrm{e}, \\
& \text { (III) } \mathrm{FeOH}_{\mathrm{ads}}+\rightarrow \mathrm{Fe}_{\mathrm{aq}}{ }^{2+}+\mathrm{OH}^{-},
\end{aligned}
$$


the second step being rate-determining. The anode current density $i_{\alpha}$ and the corrosion current density $i_{\mathrm{c}}$ according to this mechanism are respectively

$$
\begin{gathered}
i_{a}=k z F a_{\mathrm{OH}^{-}} \exp \left(\frac{\Delta \varphi}{b_{a}}\right), \\
i_{\mathrm{corr}}=k z F a_{\mathrm{OH}^{-}} \exp \left(\frac{\Delta \varphi_{\mathrm{corr}}}{b_{a}}\right),
\end{gathered}
$$

where $\Delta \varphi$ is anode overpotential and $\Delta \varphi_{\text {corr }}$ its value at the corrosion potential. The mechanism explains the maximum observed in the galvanostatic transients; it is related to reaction (I). From the kinetic point of view the time required for the electrode potential to reach its maximum value would be analogous to an induction period in a chemical reaction; if reaction (II) is rate-determining, it is reasonable to relate the induction period to the time required to build-up a certain concentration of the intermediate on the electrode surface. The theory developed by Bockris et al ${ }^{13}$ predicts that the maximum overpotential should give a Tafel line with slope of $R T / F$, as found in our experiments.

Galvanostatic transients also allow calculations of the total number of $\mathrm{C} / \mathrm{cm}^{2}$ (equal to $i \tau$ ) required to reach the maximum overpotential observed in build-up curves. Since this number is equal to the number of coulombs involved in charging the electrical double layer capacitance at the maximum potential and the number of coulombs related to the faradaic reaction, the latter is readily calculated with the data assembled in Tables 6 to 9 .

The iron surface is polycrystalline; taking an average value of the interatomic distances of iron atoms in the lattice, ${ }^{22,23}$ as $2.52 \AA$, and assuming a simple surface, the number of iron atoms is $2 \times 10^{15} / \mathrm{cm}^{2}$. We can relate the number of ions playing a part in the build-up process to the number of atoms in the metal surface. Figure 10 indicates that the number of particles, assuming that they have only one charge, tends to equal the number of available sites, when the current density is increased. At low $\mathrm{pH}$ this value is reached rapidly. The calculation suggests that the ions playing a part in the first step tend to cover the electrode area. Thus, overpotentials observed in the galvanostatic transients can be explained on the basis of the accumulation of hydroxyl ions on the electrode surface; from Fig. 10, the surface coverage at the corrosion potential is about 10 per cent.

The decrease of dissolution rate of the metal in the presence of chloride or nitrate is interesting. These ions are known to be preferentially adsorbed as compared with perchlorate. They evidently compete with hydroxyl ions for adsorption sites. The net effect is that the higher the adsorbability of the foreign anions, the lower the rate of the anodic dissolution. If anion adsorption processes are involved in the reaction and those processes are in equilibrium, the rate equation for the electrochemical reaction will have the same form as (1) except that the pre-exponential factor must include the appropriate equilibrium constants. This means that the Tafel slope is not modified, but the exchange current density is. This suggestion is supported by the fact that the experimental heats of activation previously obtained for the spontaneous dissolution of iron are different for the case of solutions containing perchlorate and chloride ions; the magnitudes of the heats of activation are in satisfactory agreement with the assumption that chloride is more strongly adsorbed than perchlorate. 
The corrosion currents calculated by the different methods employed in the present work confirm the previous values found from independent kinetic measurements, in which the corrosion current was calculated with cathodic and anodic reaction parameters, assuming for the latter a Tafel slope of $\frac{2}{3}(R T / F)$.

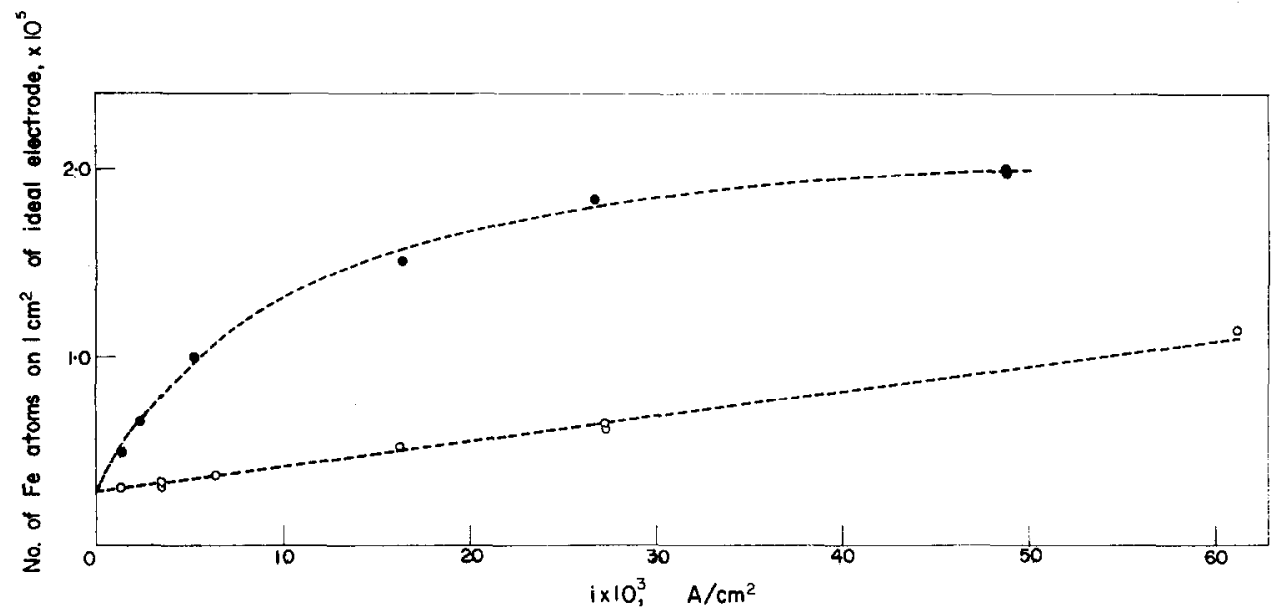

FiG. 10. Number of monovalent ions involved in the charging process up to the $E_{\max }$ vs $\log i$.

(e) $2 \mathrm{M} \mathrm{NaClO}_{4}, 0 \cdot 1 \mathrm{M} \mathrm{Fe}\left(\mathrm{ClO}_{4}\right)_{2}$. pH $2 \cdot 45,15 \cdot 5^{\circ} \mathrm{C}$.

(O) $2 \mathrm{M} \mathrm{NaClO}_{4}, 0 \cdot 1 \mathrm{M} \mathrm{Fe}\left(\mathrm{ClO}_{4}\right)_{2}$. $\mathrm{pH} 0 \cdot 20,15 \cdot 0^{\circ} \mathrm{C}$.

$2 \cdot 0 \times 10^{15}$ is the number of iron atoms in $1 \mathrm{~cm}^{2}$ of ideal electrode.

Statistical estimation of deviations from the Tafel line $2(R T / F)$ indicate that other mechanisms, requiring $b_{a}$ equal to $R T / F$ or $2 R T / F$, may be energetically close to that requiring $\frac{2}{3}(R T / F)$, derived by Bockris, Drazic and Despic, ${ }^{13}$ as indicated by those authors.

Acknowledgement-The authors are indebted to Dr T. P. Hoar for valuable criticism and advice on the preparation of this paper. The work was done with the financial support of Comisión de Investigación Científica de la Provincia de Buenos Aires and Consejo Nacional de Investigaciones Científicas y Técnicas de la Argentina.

\section{REFERENCES}

1. W. A. Rojter, W. A. Juza and E. S. Polujan, Acta Phys-Chim. URSS 10, 389 (1939).

2. M. Stern and R. M. Roth, J. Electrochem. Soc. 104, 390 (1957).

3. G. OKamoto, M. NaGaYama and N. SATo, International Commillee of Electrochemical Thermodynamics and Kinetics, 8th Meeting, Madrid, 1956, p. 445. Butterworth, London (1958).

4. T. P. Hoar and T. Hurlen, ibid, p. 445.

5. K. F. Bonhoeffer and K. E. Heusler, Z. phys. Chem. 8, 390 (1956).

6. H. KAESCHE, Z. Elektrochem. 63, 492 (1959).

7. A. C. Makrides, N. M. Komodromos and N. Hackerman, J. Electrochem. Soc. 103, 363 (1955).

8. H. Gatos, J. Electrochem. Soc. 103, 286 (1956).

9. T. P. Hoar and R. D. Holliday, J. Appl. Chem. 3, 502 (1953).

10. T. P. HoAr and T. W. FARrer, Corros. Sci. 1, 49 (1961).

11. A. C. MAKRIDES, J. Electrochem. Soc. 107, 869 (1960).

12. T. Hurlen, Acta Chem. Scand. 14, 1533 (1960).

13. J. O'M, Bockris, D. DRAZIC and A. R. DesPIC, Electrochim. Acta 4, 325 (1961).

14. J. J. Podesta and A J. Arvfa, Electrochim. Acta 10, 159 (1965).

15. A. Hickling, Electrochim. Acta 5, 161 (1961).

16. W. E. Richeson and M. EISFNBERG, J. Electrochem. Soc. 107, 642 (1959).

17. E. C. PotTer, Electrochemistry, Principles and Applications. Cleaver-Hume, London (1957). 
18. A. J. De Bethune, T. S. Licht and N. Swendeman, J. Electrochem. Soc. 106, 616 (1959).

19. P. Delahay, New Instrumental Methods of Electrochemistry. Interscience, New York (1954).

20. B. Kabanov, R. Burstein and A. Frumkin, Disc. Faraday Soc. 1, 259 (1947).

21. J. O'M. BocKRIS and H. KTTA, J. Electrochem. Soc. 108, 676 (1961).

22. C. J. Smirthels, Metals Reference Handbook. Butterworths, London (1955).

23. L. E. Sutton (Ed.), Interatomic Distances. Chemical Society, London (1958). 